\title{
Estimulação em consciência fonêmica e seus efeitos em relação à variável sexo***
}

\author{
Phonemic awareness stimulation and its effects regarding the \\ variable gender
}

Simone Raquel Sbrissa Moura*
Carolina Lisbôa Mezzomo**
Carla Aparecida Cielo**

*Fonoaudióloga. Mestre em Distúrbios da Comunicação Humana pela Universidade Federal de Santa Maria Rio Grande do Sul. Endereço para correspondência: Rua Doutor Nereu Ramos, 120 - Apto. 1002 - Itajaí - SC CEP 88301-215

(simoneraquel77@hotmail.com).

**Fonoaudióloga. Doutora em Linguística Aplicada pela Pontifícia Universidade Católica do Rio Grande do Sul. Professora Adjunto do Departamento de Fonoaudiologia da Universidade Federal de Santa Maria (RS).

***Trabalho Realizado Universidade Federal de Santa Maria (RS).

Artigo Original de Pesquisa

Artigo Submetido a Avaliação por Pares

Conflito de Interesse: não

Recebido em 11.03.2008.

Revisado em 29.04.2008; 19.07.2008; 02.09.2008; 30.11.2008.

Aceito para Publicação em 03.02.2009.

\section{Abstract}

Background: phonemic awareness stimulation and the comparison of its effects between genders. Aim: to determine the possible gain in performance in tasks involving phonemic awareness skills in boys and girls, following the development of a program to stimulate phonemic awareness. Method: participants were 18 boys and 18 girls, all with typical language development, in their second grade of Elementary Education. The study involved three steps. The first and third steps consisted of an auditory screening, speech and language assessments and the assessment of phonemic awareness skills, through the Phonological Awareness Tasks Protocol. The second step involved the planning of the phonological awaress stimulation program and its application in the classroom. Results: boys and girls presented an improvement in their performance in all of the phonological awareness tasks after the application of the stimulation program; this improvement was statistically significant. Regarding the influence of gender, it was observed that prior to the application of the stimulation program, there was a significant difference between boys and girls in the task involving the detection of a phoneme in the last position. After stimulation, this difference remained significant in the same task, and was also statistically significant for the tasks of phonemic segmentation of words with six phonemes and phoneme reversion of words with two or three phonemes. Conclusion: it is observed that girls performed better in the majority of the phonemic awareness tasks, and that the program was effective in stimulating these tasks.

Key Words: Teaching; Speech Therapy; Sex Distribution.

\section{Resumo}

Tema: estimulação em consciência fonêmica e a comparação de seus efeitos entre os sexos. Objetivo: verificar o possível ganho no desempenho em tarefas envolvendo habilidades de consciência fonêmica em meninos e meninas após desenvolvimento de programa de estimulação em consciência fonêmica. Método: a amostra foi composta de alunos da segunda série do Ensino Fundamental, sendo 18 meninos e 18 meninas, com desenvolvimento típico de linguagem. O estudo compreendeu três etapas. Na primeira e na última etapa, foram realizadas as triagens audiológicas, as avaliações fonoaudiológicas e das habilidades em consciência fonêmica através do Protocolo de Tarefas de Consciência Fonológica. Na fase intermediária, o programa de estimulação em consciência fonêmica foi previamente planejado e, em seguida, aplicado em sala de aula. Resultados: meninos e meninas apresentaram melhor desempenho após o desenvolvimento do programa de estimulação em todas as tarefas de consciência fonêmica, com diferença estatisticamente significativa. Com relação à interferência da variável sexo, se constatou que antes do programa de estimulação, houve diferença significativa entre meninos e meninas na tarefa de detecção fonêmica em posição final. Após a estimulação, essa diferença permaneceu significativa na mesma tarefa e se revelou importante estatisticamente também nas tarefas de segmentação fonêmica de palavras com seis fonemas e de reversão fonêmica para palavras com dois e três fonemas. Conclusão: percebe-se que, na maioria das tarefas em consciência fonêmica, as meninas obtiveram melhor desempenho, mesmo que em alguns casos o resultado não tenha sido estatisticamente significativo. Além disso, o programa de estimulação dessas tarefas foi eficaz.

Palavras-Chave: Ensino; Fonoterapia; Distribuição por Sexo.

Referenciar este material como:

- Moura SRS, Mezzomo CL, Cielo CA. Phonemic awareness stimulation and its effects regarding the variable gender. (original title: Estimulação em consciência - 3 fonêmica e seus efeitos em relação à variável sexo). Pró-Fono Revista de Atualização Científica. 2009 jan-mar;21(1):51-6. 


\section{Introduction}

The positive correlation between the specific ability training in phonological awareness and the reading and writing learning in clinic and educational environment is recognized by several researches1,2,3,4.

Some authors5-7 point out the importance of formal task teaching in the phonemic awareness during the literacy process, associated with explicit instruction in phoneme-grapheme.

However, there is still a lack of studies in stimulating programs, which emphasize the phonemic awareness.

Moreover, a few researchers have been concerned about assessing the influence of the sex variable related to phonological awareness skills, especially at the phonemic level.

In this context, it is possible to highlight reasearches8-9 in which differences between the sexes have not been observed, especially those related to the performance in phonological awareness tasks. However, there are studies10-11 that show the girls had a better performance in those tasks, mainly at the syllable level.

These results provide an interesting perspective with respect to complementary investigations, encoding both greater samples and criterious analysis. Neuroimaging exams have confirmed that men and women process the language differently. They have also found that women12-15 have a greater chance of having a better performance in dealing with phonological material.

This study aimed to determine the possible gain in performance in tasks involving phonemic awareness skills in boys and girls, following the development of a program to stimulate phonemic awareness.

In this research, the terminology "sex" not "gender" was used in order to cover just the binary characteristic of boys and girls, without emphasizing the socially determined aspects 16 .

The examination of phonemic awareness of second grade students is justified by the necessity of more studies about this capacity, as well as because the phonemic awareness is consolidated between seven and eight years, which corresponds to these age groups 1 .

\section{Method}

This study has had the approval of the Research Ethic Committee of the institution of origin (0037.0.243.000-06) and was authorized by the school through the Institutional Authorization Form (CONEP-Res.196/96).

In the selection of the sample, the following inclusion criteria were taken into consideration: The Consent Form (CONEP - Res. 196/96), signed by the parents or the responsible ones; the students should be between seven and eight years old and should study in the second grade of Elementary Education. As exclusion criteria, the following aspects were considered: neurological, emotional and/or apparent perceptive alterations, and/or congenital diseases; negative performance in the audiological and phonological screening; anatomophysiological alterations of the phonoarticulatory organs, of expressive oral language and comprehensive hearing.

The phonological screening in order to implement the exclusion criteria included: the audiological screening, the language, speech and orofacial motricity assessment.

The data on the emotional characteristics and the intellectual level of the students were obtained by means of written evaluations made by the Educational Psychological Service of the Institution through the access to its prontuary.

The children who presented alterations in the assessments were taken to phonoaudiological assistance and were excluded from the study.

After the previous assessments, the study group was formed by 36 second-grade students of Elementary Education, being 18 boys and 18 girls, age ranging from 7:2 to 8:8 years (average: 7:5).

After the selection of the sample, the procedures for the data collection consisted of three stages. In the first one, the children's performance in phonemic awareness tasks was assessed.

In the second, a program to stimulate phonemic awareness in this area was applied, whereas in the third and last stages, the performance in the same tasks was reassessed as a means of comparison.

In the first and in the last stages, three tasks of the Phonological Awareness Tasks Protoco1 were used, which involved the following phonemic awareness skills: Phonemic Exclusion (T1) - in initial, final and intermediary position; Phonemic Detection (T2) - in initial, final and intermediary position; Phonemic Synthesis (T3) -words with three, four, five, six and seven phonemes; Phonemic Segmentation (T4) - words with three, four, five, six and seven phonemes, and Phonemic Reversion (T5) -words with two, three, four and five phonemes.

The tasks were individually assessed in a thirtyminute single meeting, which took place in a silent room of the school, during the class time. The test 
was applied according to the regulations suggested by the author and the answers evaluated as correct in the first attempt (1st T) scored 2 points; the correct ones in the second attempt (2nd T) scored 1 point; and the incorrect ones scored 0 (zero). Each of the task subtypes would have a maximum of ten points. In this context, a score for each of the subtasks and a maximum gross score for each of the individuals could be obtained.

No criterion of approval or disapproval was considered towards the results of the children of the sample.

In the second stage, the program to stimulate the phonemic awareness was conducted. It was based on the suggested activities 17-18, which were adapted to the curriculum projects for the second grade. There was also a concern about the explicit instruction on the phoneme-grapheme correspondence, that is, the explanation that for each sound of each word there is a graphic code (grapheme) that represents it.

The program was conducted through the researcher's participation in the teacher's weekly planning meetings, so that it was possible to engage them in the preparation and execution of activities, such as written texts, poetry reciting, music, theater and games. The program, which was carried out in the classroom with the teacher's participation and or help, consisted of nine meetings of approximately forty minutes each over three weeks.

The initial and final data collected were evaluated, and the Test for Difference Between Two Proportions and The Confidence Interval Test of a Proportion with a 5\% significance level were used through the Excel program. Both tests were applied in order to analyze the sex variable before and after the stimulating program related to the success obtained, that is, related to the score obtained of ?5 in each task.

The Wilcoxon Nonparametric Tests, with p?0,10 value, were used to find out the influence of sex variable on the task performance before and after the stimulating program.

\section{Results}

In Table 1, no significant statistical difference was observed between boys and girls in the phonemic awareness task performance before and after the stimulating program was applied.

However, when the gross measures were analyzed, a better percentage in the female performance in the intermediary and final phoneme detection tasks was observed when compared to the male group. The only exception was found in the tasks in which the success was the same between them, as well as in the intermediary and final phoneme detection tasks. Also, it could be observed that the girls did better in phonemic synthesis and segmentation, which encodes a bigger number of phonemes.

After the stimulation, the girls obtained more success in tasks to detect the phoneme in the intermediary position and the phonemic reversion for words with two or three phonemes. The males had more success in both the phonemic synthesis of words with seven phonemes and the phonemic reversion for words with four or five phonemes.

Taking into account the total group of children, the statistical significance in favor of the stimulating program for eleven of the eighteen applied tasks (Table 1) could be observed. Thus, the performance of the group was significantly better in tasks of detection of the intermediary phoneme; phonemic synthesis of words with three, four, five, six and seven phonemes; phonemic segmentation for words with three, four, five, six and seven phonemes; phonemic reversion for words with two, three, four and five phonemes.

As a significant result, there was a gain of approximately of $60 \%$ in the phonemic synthesis tasks after the stimulation, especially with sevenphoneme words, as well as about a $36 \%$ gain in the reversion for words with four and five phonemes.

In Table 2, it was observed that after the development of the stimulating program, the women's better performance in all of the tasks was statistically significant.

The boys had a significant improvement in their performance in the tasks, except in the ones about final position phonemic detection and about phonemic reversion for words with two and three phonemes, in which the difference was not significant.

In this same Table, it could be seen that before the stimulating program there was a significant difference between the sexes only in the final position phonemic detection task. In Table 3, it could be realized that the boys obtained better performance in that task. After the stimulation, this difference remained statistically significant in the same task. It was considered to be favorable to the girls, though, in tasks of phonemic segmentation for words with six phonemes and in phonemic reversion ones for words with two and three phonemes.

In Table 2, it was possible to identify that the group of 36 selected children statistically had better performance in all of the phonemic awareness tasks after the development of the stimulating program. 
TABLE 1. Comparison between the performance of boys and girls in the phonemic awareness tasks before and after the stimulating program.

\begin{tabular}{|c|c|c|c|c|c|c|c|c|c|}
\hline \multirow{3}{*}{\multicolumn{2}{|c|}{ Tasks in phonemic awareness }} & \multicolumn{3}{|c|}{ Before } & \multicolumn{3}{|c|}{ After } & \multirow{2}{*}{$\begin{array}{l}\text { Before } \\
\text { Group } \\
\mathrm{N}=36\end{array}$} & \multirow{2}{*}{$\begin{array}{c}\text { After } \\
\text { Group } \\
\mathrm{N}=36 \\
\end{array}$} \\
\hline & & \multirow{2}{*}{$\begin{array}{c}\text { Boys } \\
\mathrm{N}=18 \\
\% \text { Sucess } \\
\end{array}$} & \multirow{2}{*}{$\begin{array}{c}\text { Girls } \\
\mathrm{N}=18 \\
\% \text { Sucess } \\
\end{array}$} & \multirow[t]{2}{*}{ Sig.* } & $\begin{array}{c}\text { Boys } \\
\mathrm{N}=18\end{array}$ & $\begin{array}{c}\text { Girls } \\
\mathrm{N}=18\end{array}$ & \multirow[t]{2}{*}{ Sig.* } & & \\
\hline & & & & & \%Sucess & \%Sucess & & \%Sucess & \%Sucess \\
\hline T1-Initial & \multirow{4}{*}{ Exclusion } & 100 & 100 & Ns & 100 & 100 & Ns & 100 & 100 \\
\hline T1-Final & & 100 & 100 & Ns & 100 & 100 & Ns & 100 & 100 \\
\hline $\mathrm{T} 1$-Intermediary & & 94,44 & 100 & Ns & 100 & 100 & Ns & 97,22 & 100 \\
\hline T2-Initial & & 100 & 100 & Ns & 100 & 100 & Ns & 100 & 100 \\
\hline T2-Final & \multirow{2}{*}{ Detection } & 100 & 94,44 & Ns & 100 & 100 & Ns & 97,22 & 100 \\
\hline $\mathrm{T} 2$-Intermediary & & 94,44 & 72,22 & Ns & 94,44 & 100 & Ns & 83,33 & 97,22 \\
\hline T3-3 phonemes & \multirow{5}{*}{ Synthesis } & 94,44 & 100 & Ns & 100 & 100 & Ns & 97,22 & 100 \\
\hline T3-4 phonemes & & 88,89 & 94,44 & Ns & 100 & 100 & Ns & 91,67 & 100 \\
\hline T3-5 phonemes & & 61,11 & 66,67 & Ns & 100 & 100 & Ns & 63,89 & 100 \\
\hline T3-6 phonemes & & 55,56 & 66,67 & Ns & 100 & 100 & Ns & 61,11 & 100 \\
\hline T3-7 phonemes & & 22,22 & 44,44 & Ns & 94,44 & 88,89 & Ns & 33,33 & 91,67 \\
\hline T4-3 phonemes $\mathrm{s}$ & & 77,78 & 88,89 & Ns & 100 & 100 & Ns & 83,33 & 100 \\
\hline T4-4 phonemes & \multirow{4}{*}{ Segmentation } & 77,78 & 88,89 & Ns & 100 & 100 & Ns & 83,33 & 100 \\
\hline T4-5 phonemes & & 83,33 & 83,33 & Ns & 100 & 100 & Ns & 83,33 & 100 \\
\hline T4-6 phonemes & & 72,22 & 77,78 & Ns & 100 & 100 & Ns & 75,00 & 100 \\
\hline T4-7 phonemes & & 72,22 & 83,33 & Ns & 100 & 100 & Ns & 77,78 & 100 \\
\hline T5-2 e 3 phonemes & \multirow[t]{2}{*}{ Reversion } & 83,33 & 83,33 & Ns & 94,44 & 100 & Ns & 83,33 & 97,22 \\
\hline T5-4 e 5 phonemes & & 55,56 & 55,56 & Ns & 94,44 & 88,89 & Ns & 55,56 & 91,67 \\
\hline
\end{tabular}

Ns - Not significant S - Significant Sig* - Statistical Significance

TABLE 2. Analysis of the statistical significance value related to the performance in phonemic awareness tasks between males and females individually, and the before and after stimulating program.

\begin{tabular}{|c|c|c|c|c|c|c|}
\hline Tasks in phonen & awareness & $\begin{array}{l}\text { Boys before/after } \\
\text { stimulating } \\
\text { Sig.* }\end{array}$ & $\begin{array}{c}\text { Girls before/after } \\
\text { stimulating } \\
\text { Sig. * }\end{array}$ & $\begin{array}{c}\text { Boys } \\
\text { versus } \\
\text { Girls } \\
\text { Before } \\
\text { Sig. * }\end{array}$ & $\begin{array}{c}\text { Boys } \\
\text { versus } \\
\text { Girls } \\
\text { After } \\
\text { Sig. * }\end{array}$ & $\begin{array}{c}\text { Before } \\
\text { versus } \\
\text { After the stimulation } \\
\text { Group }(\mathrm{n}=36) \\
\text { Sig.* }\end{array}$ \\
\hline T1-Initial & \multirow{4}{*}{ Exclusion } & 0,0820 & 0,0803 & 0,9417 & 1,00 & 0,0115 \\
\hline T1-Final & & 0,0190 & 0,0710 & 0,8563 & 0,3449 & 0,0032 \\
\hline -Intermediary & & 0,0463 & 0,0188 & 0,4706 & 0,3449 & 0,0022 \\
\hline T2-Initial & & 0,0157 & 0,0005 & 0,3365 & 1,00 & 0,0001 \\
\hline T2-Final & \multirow{4}{*}{ Deteccion } & 0,2285 & 0,0001 & 0,0689 & 0,0395 & 0,0001 \\
\hline :-Intermediary & & 0,0030 & 0,0058 & 0,8217 & 0,2709 & 0,0001 \\
\hline 3-3 phonemes & & 0,0026 & 0,0001 & 0,8945 & 0,1632 & 0,0001 \\
\hline 3-4 phonemes & & 0,0003 & 0,0001 & 0,6040 & 0,6949 & 0,0001 \\
\hline $3-5$ phonemes & \multirow[t]{5}{*}{ Synthesis } & 0,0005 & 0,0001 & 0,9238 & 0,3729 & 0,0001 \\
\hline 3-6 phonemes & & 0,0009 & 0,0006 & 0,8358 & 0,8729 & 0,0001 \\
\hline 3-7 phon emes & & 0,0001 & 0,0006 & 0,3876 & 0,5607 & 0,0001 \\
\hline 4-3 phonemes & & 0,0014 & 0,0091 & 0,4481 & 0,6205 & 0,0001 \\
\hline 4-4 phonemes & & 0,0170 & 0,0296 & 0,4709 & 0,5744 & 0,0011 \\
\hline 4-5 phonemes & \multirow{4}{*}{ Segmentation } & 0,0034 & 0,0920 & 0,5772 & 0,3386 & 0,0009 \\
\hline 4-6 phonemes & & 0,0174 & 0,0064 & 0,2511 & 0,0349 & 0,0005 \\
\hline 4-7 phonemes & & 0,0035 & 0,0345 & 0,4057 & 0,8363 & 0,0003 \\
\hline $\mathrm{T} 5-2$ e 3 & & 0,2565 & 0,0015 & 0,7709 & 0,0410 & 0,0022 \\
\hline $\begin{array}{l}\text { phonemes } \\
\text { T5-4 e } 5 \\
\text { phonemes }\end{array}$ & Reversion & 0,0251 & 0,0006 & 0,7023 & 0,6310 & 0,0001 \\
\hline
\end{tabular}

Sig.*: Statistical Significance. 
TABLE 3. Female and male performance before and after the stimulating program by ranking estimation.

\begin{tabular}{|c|c|c|c|c|c|}
\hline \multirow{3}{*}{\multicolumn{2}{|c|}{ Phonemic awareness tasks }} & \multicolumn{2}{|c|}{ Before } & \multicolumn{2}{|c|}{ After } \\
\hline & & \multirow{2}{*}{$\begin{array}{c}\text { Boys }(\mathrm{N}=18) \\
\text { Average Score }\end{array}$} & \multirow{2}{*}{$\begin{array}{c}\text { Girls }(\mathrm{N}=18) \\
\text { Average Score }\end{array}$} & \multirow{2}{*}{$\frac{\text { Boys }(\mathrm{N}=18)}{\text { Average Score }}$} & \multirow{2}{*}{$\begin{array}{c}\text { Girls }(\mathrm{N}=18) \\
\text { Average Score }\end{array}$} \\
\hline & & & & & \\
\hline T1-Initial & Exclusion & 18,61 & 18,39 & 18,50 & 18,50 \\
\hline T1-Final & & 18,78 & 18,22 & 19,0 & 18,0 \\
\hline T1-Intermediary & & 17,44 & 19,56 & 18,0 & 19,0 \\
\hline T2-Initial & & 20,08 & 16,92 & 18,50 & 18,50 \\
\hline T2-Final & Deteccion & 21,56 & 15,44 & 16,50 & 20,50 \\
\hline $\mathrm{T} 2$-Intermediary & & 18,08 & 18,92 & 16,64 & 20,36 \\
\hline T3-3 phonemes & & 18,75 & 18,25 & 17,50 & 19,50 \\
\hline T3-4 phonemes & & 19,42 & 17,58 & 18,0 & 19,0 \\
\hline T3-5 phonemes & Synthesis & 18,31 & 19,69 & 17,06 & 19,94 \\
\hline T3-6 phonemes & & 18,11 & 18,89 & 18,78 & 18,22 \\
\hline T3-7 phonemes & & 16,97 & 20,03 & 19,53 & 17,47 \\
\hline T4-3 phonemes & & 17,22 & 19,78 & 18,06 & 18,94 \\
\hline T4-4 phonemes & & 17,36 & 19,64 & 18,0 & 19,0 \\
\hline T4-5 phonemes & Segmentation & 17,58 & 19,42 & 19,44 & 17,56 \\
\hline T4-6 phonemes & & 16,56 & 20,44 & 15,92 & 21,08 \\
\hline T4-7 phonemes & & 17,08 & 19,92 & 18,22 & 18,78 \\
\hline T5-2 e 3 phonemes & & 19,03 & 17,97 & 15,33 & 21,67 \\
\hline T5-4 e 5 phonemes & Reversion & 19,19 & 17,81 & 17,69 & 19,31 \\
\hline
\end{tabular}

\section{Discussion}

In general, there was not a statistical significance related to the sex in the phonemic awareness task performances, which corroborates the results of the other studies8-9 already done.

Before the stimulating program, the girls' performance only in the final position phoneme detection task was statistically worse than the boys', confirming the findings, which pointed out this difference in the phonological awareness performance tasks, favoring girls11.

During the reassessment, the data showed the statistical significance related to sex exclusively in three phonemic awareness tasks, which include the final phoneme detection. However, it showed a better average score for girls, which is similar to the findings of this research11.

It can be pointed out here that the phoneme detection may be done in the absence of the phonemic awareness, since the phonetic tips, such as duration and phoneme intensity, may help this detection, which can be considered a holistic way of phonological awareness1.

The female performance had a higher percentage than the male in the majority of the tasks, which holds true according to the results of a research that used the same assessment instruments 11 . These results, which are corroborated by scientific evidences, suggest that it is easier for girls to learn the reading and writing skills19.

A possible explanation for the girls's superiority may be linked to the fact that the neuroimaging exams found a better language processing in females12-15.

About the efficiency of the stimulating program, the results indicated that the children of both sexes displayed a significantly better performance in phonemic awareness after the training. In this context, the intensive training in phonemic awareness may contribute to the development of this ability 2,5 with more significant effects when it is combined with the teaching of graphophonemic correspondences5,20-22.

It is also important to point out that, because the studied group comes from a private school, the results of this research should be limited to this kind of population. However, there are studies23-24 in which no significant differences in the phonemic awareness performance were found, even after the phonological awareness stimulation, associated with the graphophonemic correspondence training23 between students from public and private schools. These results suggest that the phonemic awareness performance may not be a consistent variable.

\section{Conclusion}

After the stimulating program was applied, a statistically significant difference favorable to the female sex in the task performance to detect the final phoneme, to segment the words with six phonemes and to reverse phonemically words with two and three phonemes was found. 
Although there was not statistical significance in the other phonemic awareness tasks, this study found out a qualitative tendency for better performance in the females.

The stimulating program proposed has had positive results about all the abilities worked with both sexes. However, as the differences were not striking, the specific stimulation by sex would not be justified.

\section{References}

1. Cielo CA. Habilidades em consciência fonológica em crianças de 4 a 8 anos de idade. Pró-Fono Revista de Atualização Científica. 2002;14(3):301-12.

2. Cárnio MS, Santos D. Evolução da consciência fonológica em alunos do ensino fundamental. Pró-Fono Revista de Atualização Científica. 2005;17(2):195-200.

3. Capellini AS, Padula NAMR, Ciasca SM. Desempenho de escolares com distúrbio específico de leitura em programa de remediação. Pró-Fono Revista de Atualização Científica. 2004;16(3):261-74.

4. Laing S, Espeland W. Low intensity phonological awareness training in a preschool classroom for children with communication impairment. Journal of Communication Disorders. 2005;38:65-82.

5. Paula GR, Mota HB, Keske-Soares MA. A terapia em consciência fonológica no processo de alfabetização. PróFono Revista de Atualização Científica. 2005;17(2):175-84.

6. Hatcher PJ, Hulme C, Snowling MJ. Explicit phoneme training combined with phonic reading instruction helps young children at risk of reading failure. Journal of Child Psychology and Psychiatry. 2004;45:338-58.

7. Hulme C, Snowling M, Caravolas M, Carrol J. Phonological skills are (probably) one cause of success in learning to read: a comment on castles and colt heart. Scientific Studies of Reading. 2005;9(4):351-65.

8. Wallach L, Wallach MA, Dozier MG. Poor Children learning to read do not have trouble with auditory discrimination but do have trouble with phoneme recognition. Journal of Educational Psychology. 1994;69(1):36-9.

9. Maluf MR, Barrera SD. Consciência fonológica e linguagem escrita em pré-escolares. Psicologia-Reflexão e Crítica. 1997;10(1):125-45.

10. Meneses MS, Lozi GP, Souza LR, Assencio-Ferreira VJ. Consciência fonológica: diferenças entre meninos e meninas. Revista CEFAC. 2004;6(3):242-6.

11. Andreazza-Balestrin C. Relação entre desempenho em consciência fonológica e a variável sexo, na infância [dissertação]. Santa Maria: Universidade Federal de Santa Maria; 2007.

12. Vallet ER. Fatores neuropsicológicos críticos. In: Vallet ER. Dislexia: uma abordagem neuropsicológica para a educação de crianças com graves desordens de leitura. São Paulo: Manole; 1990. p. 11-7.
Through this work, the efficiency of the program to stimulate the phonemic awareness related to the better performance of boys and girls in those tasks could be proved.
13. Knaus TA, Bollich AM, Corey DM, Lemen LC, Foundas AL. Sex-linked differences in the anatomy of the perisylvian language cortex: a volumetric MRI study of gray matter volumes. Neuropsychology. 2004;18:738-47.

14. Rabinowicz T, Dean DE, Petetot JM, Courten-Myers GM. Gender differences in the human cerebral cortex: more processes in females. Journal of Child Neurology. 1999;14(2)-98-107.

15. Luders E, Marr KL, Thompson PM, Rex DE, Jancke L, Steinmetz H, Toga AW. Gender differences in cortical complexity. Nature Neuroscience. 2004;7:799-800.

16 Olinto MTA. Reflexões sobre o uso de conceito de gênero e/ou sexo na epidemiologia: um exemplo nos modelos hierarquizados de análise. Revista Brasileira de Epidemiologia. 1998;1(2):161-9.

17. Capovilla AG, Capovilla FC. Problemas de leitura e escrita: como identificar, prevenir e remediar numa abordagem fônica. São Paulo: Memnon; 2003.

18. Adams MJ, Forman BR, Lundberg I, Beeler T. Consciência fonológica em crianças pequenas. Porto Alegre: Artmed; 2006.

19. Schatschneider C, Fletcher JM, Francis D, Carlson CD, Foorman B. Kindergarten prediction of reading skills: longitudinal comparative analysis. Journal of Educational Psychology. 2004;96(2):265-82.

20. McGuinness D, McGuinness C e Donohue J. Phonological training and the alphabet principle: Evidence for reciprocal causality. Reading Research Quarterly. 1995;30:830-52.

21. Schneider W, Roth E e Ennemoser M. Training phonological skills and letter knowledge in children at risk for dyslexia: A comparison of three kindergarten intervention programs. Journal of Educational Psychology. 2000;92(2):284-95.

22. Yeh SS. An evaluation of two approaches for teaching phonemic awareness to children in Head Start. Early Childhood Research Quarterly. 2003;18:513-29.

23. Capovilla AGS, Capovilla FC. Efeitos do treino de consciência fonológica em crianças com baixo nível sócio econômico. Psicologia-Reflexão e Crítica. 2000;13(1):7-24.

24. Pedras CTPA, Geraldo T, Crenitte PAP. Consciência fonológica em crianças de escola pública e particular. Revista da Sociedade Brasileira de Fonoaudiologia. 2006;11(2):65-9. 